\title{
Life Cycle Assessment of a Highly Diverse Vegetable Multi-Cropping System in Fengqiu County, China
}

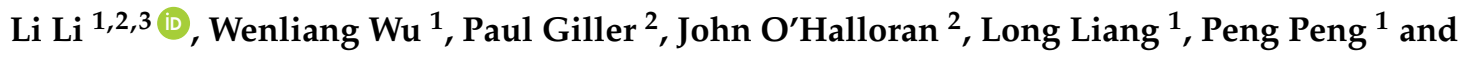 \\ Guishen Zhao ${ }^{1, *}$ \\ 1 College of Resources and Environmental Sciences, China Agricultural University, Beijing 100193, China; \\ lilee512@cau.edu.cn (L.L.); wuwenl@cau.edu.cn (W.W.); s20163030219@cau.edu.cn (L.L.); \\ ppecological@cau.edu.cn (P.P.) \\ 2 School of Biological, Earth and Environmental Sciences, University College Cork, Distillery Fields, \\ North Mall, T23 N73K Cork, Ireland; p.giller@ucc.ie (P.G.); j.ohalloran@ucc.ie (J.O.) \\ 3 International Ecosystem Management Partnership, Institute of Geographic Sciences and Natural Resources \\ Research, Chinese Academy of Sciences, Beijing 100102, China \\ * Correspondence: zhgsh@cau.edu.cn; Tel.: +86-(10)-6273-2222; Fax: +86-(10)-6273-2498
}

Received: 30 January 2018; Accepted: 26 March 2018; Published: 27 March 2018

check for updates

\begin{abstract}
Agricultural biodiversity usually leads to greater sustainability in production practices. To understand the environmental implications of the development of village-level multi-cropping in rural China, we compared the environmental impact of a highly diverse vegetable multi-cropping system to a conventional wheat/maize rotation system based on the method of life cycle assessment (LCA). Using household level cultivation data, this study examined the gate-to-gate environmental impacts of on-site cultivation practices relating to the production of 10,000 nutrient equivalent units. Results show that vegetable multi-cropping resulted in decreased average land requirement, and diesel, water and electricity usage by $69.8 \%, 62.2 \%, 71.7 \%$, and $63.4 \%$, respectively, while average nitrogen (Total $\mathrm{N})$, phosphorus $\left(\mathrm{P}_{2} \mathrm{O}_{5}\right)$, and potassium $\left(\mathrm{K}_{2} \mathrm{O}\right)$ usage in vegetable multi-cropping systems decreased by $16.3 \%, 42.1 \%$, and $75.8 \%$, respectively. Additional corresponding effects led to a decrease in the total global warming, eutrophication, and acidification potentials from external inputs by $21.6 \%, 16.7 \%$, and $16.2 \%$ of the entire system, respectively. Moreover, the midpoint human toxicity potential from pesticide usage of the vegetable multi-cropping system was lower than that of the conventional system. However, the midpoint eco-toxicity potential from pesticide usage was higher due to certain highly toxic substances, and both human and eco-toxicity potentials from heavy metals were all higher by a few orders of magnitudes. Thus, to mitigate these detrimental consequences, some related measures are proposed for sustainable practices in the future implementation of multi-cropping systems.
\end{abstract}

Keywords: life cycle assessment; multi-cropping; nutrient equivalent; biodiversity; sustainable development

\section{Introduction}

Worldwide agricultural intensification has been found to negatively affect agro-ecosystem services [1-5]. China has one of the largest global agro-industries and its high crop yield has been achieved through the increased use of fertilizers [6,7] which has in turn led to adverse effects such as increased greenhouse gas emissions [8-10], and eutrophication [11] and acidification of freshwaters $[12,13]$. In this context, innovative approaches must be considered to address the need for agricultural sustainability. 
Spatial multi-cropping has been found to be effective in promoting ecosystem services and sustainability in agricultural landscapes [2,3,14-16]. Even though no national-level scheme has been proposed to date in China, individual cases can be found in most traditional agricultural regions where farmers from individual villages introduced multi-cropping crops, such as vegetables, which usually resulted in an increased economic income. A representative example can be found in Fengqiu County, Henan Province, where an entire village concentrates on multi-cropping vegetable cultivation (X.J. Li, Personal communication, 20 June 2011). Local census data indicated that the village has been yielding a per capita income of two to three times that of a traditional village, with winter wheat (Triticum aestivum L.) and maize (Zea mays) rotation in previous years.

While researchers have shown that agricultural biodiversity, especially through multi-cropping, generally benefits agricultural sustainability, most have focused on the aboveground and belowground changes in specific crops and the interactions brought about when one or two nutrient-facilitating or soil-conserving species have been introduced $[3,14,17]$. As such, the broader environmental impact of cropping systems comprised of high levels of crop diversity has often been overlooked. As multi-cropping generally requires more external inputs, adopting such a system may add to already elevated environmental loads. Understanding the environmental impact of such a change, even at a small scale, can not only aid in the development of local livelihood, but it can also aid in regional level sustainability and policy making.

Evaluating and comparing production systems with such complexity can benefit from the use of life cycle assessment methodology [18,19]. Life Cycle Assessment (LCA) is a method for evaluating and quantifying the environmental impacts of a product, system, or a series of activities by listing all the resources used and waste produced [20]. Its scope can cover all aspects of the agricultural process, including the extraction of raw materials, production and transportation of products, retailing, and arable farming [18]. The environmental impacts are grouped and quantified in a common functional unit, and evaluated in a comprehensive index or in their respective environmental categories [18,21].

Life cycle approaches have been increasingly adopted in agricultural research, but certain challenges still need to be addressed to ensure their rigorousness in supporting policy decisions. Firstly, while most LCA studies identify agricultural intensification as a more environmental-friendly production method, [22,23], current LCA methods often neglect long-term sustainability issues around soil quality, fertility, and erosion, as well as ecosystem service risks due to intensification and related biodiversity loss [24]. While these aspects are often characterized at the landscape level, agricultural LCA is often field-level based and, therefore, fails to acknowledge them, resulting in sub-optimal policies and actions [24]. Secondly, agricultural LCA inventory data are more variable than for other industries; for instance, two or more chemicals with similar or vastly different active ingredients might be used for similar purposes. This is especially prevalent in developing countries where a lack of appropriate knowledge and training results in the extensive misuse of agro-chemicals in farmlands [25]. The lack of LCIA (life cycle impact assessment) models meeting the spatial and temporal requirements of case-specific LCA research further adds to the uncertainty of impact assessment results [26]. In developing countries such as China, the fragmentation of arable land and the relatively under-regulated usage of agro-chemicals, generally resulting in insufficient census data, make the extrapolation of LCA results problematic. The extreme variation of chemical substances used in Chinese farmlands presents another difficulty in performing LCA, as most life cycle inventory models do not currently include such a wide range of chemical substance properties. Lastly, socio-economic aspects of sustainability, such as working conditions, welfare, and cultural values are often neglected in agricultural LCA studies [24].

Studies using an LCA methodology have confirmed the positive effects of crop rotation, such as the added benefit of $\mathrm{N}, \mathrm{P}$, and $\mathrm{K}$ resources $[27,28]$. Unlike crop rotations, multi-cropping involves crops grown in the same field in both spatial and temporal successions, which has often been overlooked in LCA studies. This current paper aims to assess the environmental impacts of a representative vegetable multi-cropping system in rural China. Using first-hand survey data rather than census data, this paper 
documents and assesses detailed external inputs, especially chemical usage in arable farming practices. It also addresses the need for a suitable functional unit when assessing complex agricultural systems where multiple crop types are involved.

\section{Materials and Methods}

\subsection{Study Area}

The study area is in Fengqiu County, Henan Province, in the central-eastern region of China, to the north of the Yellow River (Figure 1). A representative site was selected for each cultivation system, similar to the approach used by Wang, et al. [29]. Village Chang-zhai (CZ) was selected as a representative vegetable multi-cropping system. Though other villages following in CZ's footsteps have been identified in the area, local census data and interviews with county leaders suggested that these villages were less successful and, therefore, less suitable for representing the multi-cropping process. The matching traditional winter wheat/maize rotation village was Zhu-cun-pu (ZCP). This was selected by first matching the general soil composition with provincial soil maps (soil type mud-sand formation, similar to Fluventic Ustochrept of the USDA classification) [30] overlaid on village distribution maps, then ordering potential villages using socio-economic data to find the longest-standing traditional wheat/maize village in the region with stable cultivation patterns.
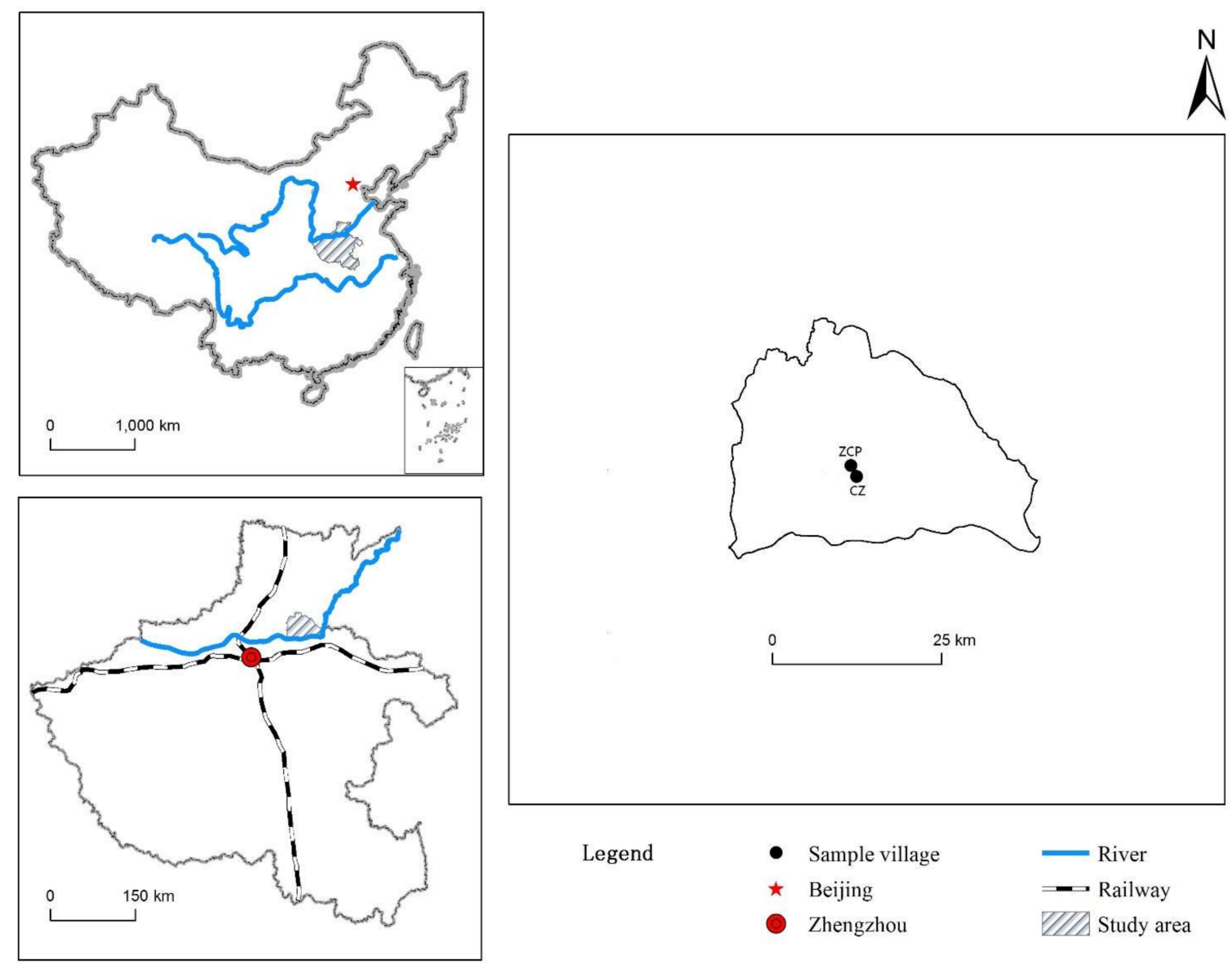

Figure 1. Map of the study area and location of the villages selected.

In 2011, one hundred households were randomly selected and interviewed face to face in both CZ and ZCP to obtain detailed cultivation data, within which a comparable baseline was established between the traditional elements of each village maintaining a winter wheat/maize rotation to ensure the rigorousness of the comparisons of environmental impacts. Follow-up interviews which 
randomly sampled previously interviewed households were conducted for two consecutive years (2012-2013) to ensure the stability of data throughout the study period. Preliminary data treatment was performed to exclude data from households who relied on revenues other than farming, such as migrant working or retailing farming materials; this ruled out 14 households in $\mathrm{CZ}$, and 10 households in ZCP. The household data were aggregated based on each crop type, and then assessed with respect to each environmental impact category.

Village $\mathrm{CZ}$ cultivated a total of 22 crop species, including wheat (Triticum aestivum), maize (Zea mays), peanut (Arachis hypogaea), sweet potato seedling (Ipomoea batatas), garlic (Allium sativum), bok choi (Brassica rapa), coriander (Coriandrum sativum), spinach (Spinacia oleracea), hot pepper (Capsicum sp.), eggplant (Solanum melongena), cauliflower (Brassica oleracea), romaine lettuce (Lactuca sativa L. var. longifolia), rape (Brassica chinensis), scallion (Allium fistulosum), potato (Solanum tuberosum), carrot (Daucus carota), onion (Allium cepa), celery (Apium graveolens), Chinese wax gourd (Benincasa hispida), and cabbage (Brassica oleracea). Village ZCP only cultivated four crops, including wheat, maize, peanut, and sweet potato. Sweet potato seedlings were cultivated for horticultural purposes rather than direct consumption.

\subsection{Assessment Goal and Scope}

This study aimed to compare the environmental impacts of the different agricultural systems, emphasizing the cultivation differences, including tillage, sowing, irrigation, fertilization, and the application of pesticides. Therefore, the study scope was limited to the arable land (farm gate-to-farm gate), excluding the manufacturing, packaging, and transportation of raw materials (chemicals and farming tools), and the marketing of the produce. These processes, in the Chinese rural areas, are often handled by multiple layers of intermediaries, and are difficult to quantify. The displacement of materials and tools within the arable land relied mainly on manual labor, and thus was also excluded in the present study.

\subsection{Functional Unit}

Traditionally, factors such as crop yield, economic income, and cultivation area have been the primary choice of functional unit for performing LCA studies in an agricultural setting [18]. In fact, farmland products are not always directly comparable as they might offer a vast range of qualitative properties. This emphasizes the need for the use of intrinsic nutrient values as functional units for comparison. Such examples include the use of energy equivalents and specific nutritional content [22,31-35]. However, none of these previous studies have involved comparisons among such a range of products. This present study involved the assessment of 22 different products, thus an appropriate functional unit would need to consider the different nutrients provided, resulting in a balanced evaluation. Here, the combined nutritional equivalent unit was used in LCA, and defined as the mean of the respective ratios (percent of daily recommended intake values) of the main nutrients (calories, vitamin A, carotene, vitamin C, vitamin E, calcium, phosphorus, potassium, sodium, magnesium, iron, zinc, selenium, copper, and manganese; Table A2) to those recommended by the Chinese National Institute for Nutritional Health [36] (Table 1). The functional unit of the study was set as ten thousand $(10,000)$ nutrient equivalent units. This functional unit allows us to make direct comparisons among food and cash crops that are variable in production yield and dietary needs. As sweet potato seedlings were not cultivated for direct consumption (see above), the nutrient values of the seedling itself were used as equivalents (Table 1). 
Table 1. Calculated nutritional equivalent (NE) units of all produces cultivated in the study villages.

\begin{tabular}{cccc}
\hline Produce & NE/kg & Produce & NE/kg \\
\hline Wheat (Triticum aestivum) & 1.73 & Eggplant (Solanum melongena) & 0.32 \\
Maize, dried, yellow, (Zea mays) & 1.21 & Cauliflower (Brassica oleracea) & 0.73 \\
Peanut (Arachis hypogaea) & 1.54 & Romaine lettuce (Lactuca sativa) & 0.59 \\
Sweet potato, red flesh (Ipomoea batatas) & 0.67 & Rape, small (Brassica chinensis) & 1.12 \\
Garlic stalk (Allium sativum) & 0.69 & Scallion (Allium fistulosum) & 0.44 \\
Garlic bulb & 0.69 & Potato (Solanum tuberosum) & 0.56 \\
Sweet potato seedling & 0.87 & Carrot, red (Daucus carota) & 1.31 \\
Bok choi, white (Brassica rapa) & 0.49 & Onion bulb (Allium cepa) & 0.30 \\
Coriander leaf (Coriandrum sativum) & 1.27 & Celery, white (Apium graveolens) & 0.51 \\
Spinach (Spinacia oleracea) & 1.79 & Winter melon (Benincasa hispida) & 0.26 \\
Hot pepper, red (Capsicum sp.) & 1.78 & Cabbage (Brassica oleracea) & 0.55 \\
\hline
\end{tabular}

\subsection{Life Cycle Inventory}

The life cycle inventory detailed all external inputs into the two cropping systems (Table 2), covering all cultivation processes, including land use, ploughing and sowing, irrigation, fertilization, pesticide use, and harvesting. These were calculated as follows:

$$
\text { Substances used per funcitonal unit }=10,000 \times \frac{\text { Substance (resources) used }}{\text { Crop yield }(\mathrm{kg})} / \mathrm{NE} \mathrm{\textrm {kg } ^ { - 1 }}
$$

where Substance (resources) used refers to the amount of external inputs (land area, water, diesel, etc.; see Table 2 for listed inputs) per hectare; Crop yield (kg) refers to the total crop yield per hectare; NE is the nutritional equivalent of respective crop types (Table 1); 10,000 was the constant selected for an easier calculation and representation of results.

Table 2. Life cycle inventory of the average amounts of substances used in the two cultivation systems per ten thousand nutrient equivalent units.

\begin{tabular}{|c|c|c|c|c|c|}
\hline \multirow[t]{2}{*}{ Cultivation Process } & \multirow[t]{2}{*}{ External Inputs } & \multirow[t]{2}{*}{ Description } & \multirow[t]{2}{*}{ CAS RN } & \multicolumn{2}{|c|}{$\begin{array}{c}\text { Amount per } 10,000 \text { Nutrient } \\
\text { Equivalent Units }\end{array}$} \\
\hline & & & & ZCP Mean & CZ Mean \\
\hline General & Land used, $\mathrm{m}^{2}$ & - & - & $6.93 \times 10^{3}$ & $2.09 \times 10^{3}$ \\
\hline Irrigation/fertilization & Water, L & Ground water & - & $4.53 \times 10^{3}$ & $1.71 \times 10^{3}$ \\
\hline $\begin{array}{l}\text { Plowing/sowing/ } \\
\text { irrigation/harvesting }\end{array}$ & Diesel, L & - & - & $7.30 \times 10^{1}$ & $2.06 \times 10^{1}$ \\
\hline Irrigation & Electricity, kWh & Thermal electricity & - & $7.16 \times 10^{2}$ & $2.62 \times 10^{2}$ \\
\hline Fertilization & Nitrogen, kg & $\mathrm{N}$ eq. & $7727-37-9$ & $7.58 \times 10^{2}$ & $6.33 \times 10^{2}$ \\
\hline Fertilization & $\begin{array}{l}\text { Phosphorus } \\
\text { pentoxide, kg }\end{array}$ & $\mathrm{P}_{2} \mathrm{O}_{5}$ eq. & $1314-56-3$ & $2.95 \times 10^{2}$ & $1.71 \times 10^{2}$ \\
\hline Fertilization & Potassium oxide, $\mathrm{kg}$ & $\mathrm{K}_{2} \mathrm{O}$ eq. & $12136-45-7$ & $3.98 \times 10^{2}$ & $9.63 \times 10^{1}$ \\
\hline Fertilization & Chicken manure & - & - & - & $7.11 \times 10^{3}$ \\
\hline Fertilization & Swine manure & - & - & - & $2.23 \times 10^{2}$ \\
\hline Insecticide & Dimethoxon, kg & $\mathrm{C}_{5} \mathrm{H}_{12} \mathrm{NO}_{4} \mathrm{PS}$ & $1113-02-6$ & 1.25 & 1.24 \\
\hline Insecticide & Cypermethrin, kg & $\mathrm{C}_{22} \mathrm{H}_{19} \mathrm{Cl}_{2} \mathrm{NO}_{3}$ & $52315-07-8$ & $2.68 \times 10^{-2}$ & $2.92 \times 10^{-2}$ \\
\hline Insecticide & Methamidphos, kg & $\mathrm{C}_{2} \mathrm{H}_{8} \mathrm{NO}_{2} \mathrm{PS}$ & $10265-92-6$ & $7.73 \times 10^{-2}$ & $2.04 \times 10^{-2}$ \\
\hline Insecticide & Imidacloprid, kg & $\mathrm{C}_{9} \mathrm{H}_{10} \mathrm{ClN}_{5} \mathrm{O}_{2}$ & 138261-41-3 & $1.60 \times 10^{-4}$ & $2.35 \times 10^{-3}$ \\
\hline Insecticide & Dimite, $\mathrm{kg}$ & $\mathrm{C}_{14} \mathrm{H}_{12} \mathrm{Cl}_{2} \mathrm{O}$ & $80-06-8$ & $3.06 \times 10^{-2}$ & $2.25 \times 10^{-3}$ \\
\hline Insecticide & Phoxim, kg & $\mathrm{C}_{12} \mathrm{H}_{15} \mathrm{~N}_{2} \mathrm{O}_{3} \mathrm{PS}$ & $14816-18-3$ & $5.78 \times 10^{-3}$ & $1.02 \times 10^{-1}$ \\
\hline Fungicide & Cymoxanil, kg & $\mathrm{C}_{7} \mathrm{H}_{10} \mathrm{~N}_{4} \mathrm{O}_{3}$ & $57966-95-7$ & & $1.08 \times 10^{-4}$ \\
\hline Fungicide & Mancozeb, kg & [C4H6MnN2S4]xZny & 8018-01-7 & & $8.66 \times 10^{-4}$ \\
\hline Fungicide & Chlorothalonil, kg & $\mathrm{C}_{8} \mathrm{Cl}_{4} \mathrm{~N}_{2}$ & $1897-45-6$ & & $1.83 \times 10^{-2}$ \\
\hline Herbicide & Atrazine, kg & $\mathrm{C}_{8} \mathrm{H}_{14} \mathrm{ClN}_{5}$ & 1912-24-9 & $7.12 \times 10^{-2}$ & $6.01 \times 10^{-2}$ \\
\hline
\end{tabular}


Table 2. Cont.

\begin{tabular}{cccccc}
\hline \multirow{2}{*}{ Cultivation Process } & \multirow{2}{*}{ External Inputs } & \multirow{2}{*}{ Description } & CAS RN & \multicolumn{2}{c}{$\begin{array}{c}\text { Amount per 10,000 Nutrient } \\
\text { Equivalent Units }\end{array}$} \\
\cline { 4 - 5 } & & & & ZCP Mean & CZ Mean \\
\hline Herbicide & Pendimethalin, $\mathrm{kg}$ & $\mathrm{C}_{13} \mathrm{H}_{19} \mathrm{~N}_{3} \mathrm{O}_{4}$ & $40487-42-1$ & $3.43 \times 10^{-2}$ & $1.72 \times 10^{-1}$ \\
\hline Herbicide & Acetochlor, $\mathrm{kg}$ & $\mathrm{C}_{14} \mathrm{H}_{20} \mathrm{ClNO}_{2}$ & $34256-82-1$ & $6.44 \times 10^{-2}$ & $4.71 \times 10^{-2}$ \\
\hline \multicolumn{4}{c}{$\mathrm{ZCP}$, village $\mathrm{Zhu}$-cun-pu; $\mathrm{CZ}$, village Chang-zhai; eq., equivalent. }
\end{tabular}

In addition to rain, submersible electric water pumps were the sole irrigation method in the study area. In the villages being studied, two pump models were used, with a designed maximum water flow of $20 \mathrm{~m}^{3} / \mathrm{h}(3 \mathrm{~kW})$ and $25 \mathrm{~m}^{3} / \mathrm{h}(4 \mathrm{~kW})$, respectively (at 220 voltages, numbers in brackets denote working capacities). However, these pumps were often performing at a reduced capacity due to mechanical wear, instability of the dedicated electrical grids, and low underground water levels. It was estimated from interviews with experienced farmers and village leaders that the actual water flows of the pumps were approximately $8 \mathrm{~m}^{3} / \mathrm{h}\left(3 \mathrm{~kW}\right.$, mean value of $\left.6-10 \mathrm{~m}^{3} / \mathrm{h}\right)$ and $10 \mathrm{~m}^{3} / \mathrm{h}(4 \mathrm{~kW}$, mean value of $8-12 \mathrm{~m}^{3} / \mathrm{h}$ ), respectively. Walking tractors (two-wheel tractor/ single-axle tractor) were the predominant machinery used for tillage and sowing, and combine harvesters were used during harvest. Interviews with experienced farmers and village leaders put their energy usage at $26.25 \mathrm{~L} / \mathrm{ha}$ (mean value of $22.5-30 \mathrm{~L} / \mathrm{ha}$ ) and $38.75 \mathrm{~L} / \mathrm{ha}$ (mean value of $37.5-45 \mathrm{~L} / \mathrm{ha}$ ) of diesel, respectively (based on the questionnaires).

Fertilizer and other chemical usages were highly diverse, including 11 types of synthetic chemical fertilizers, 2 types of manures (swine and chicken), 8 pesticides, 2 fungicides, and 9 herbicides (Table 2; Table A1). Nitrogen input in the form of ammonium $\left(\mathrm{NH}_{4}{ }^{+}\right)$was uncommon and in very small quantities (used as after fertilizers in the form of Diammonium Phosphate), and was therefore excluded in the life cycle impact assessment stage. Pesticide usage in the region differed greatly in terms of crop type and application time (Table 2; Table A1). Just using selective chemicals in the analysis, whether based on application mass or frequency, might overlook substances used in small quantities that would in fact cause substantial environmental impacts [37]. To avoid such errors, the approach taken was to first record all chemicals being sold in the local supply stores, then, use detailed information and photographs, and interview farmers about the exact substance type and application pattern. These results were then converted to the amount of active ingredients for further analysis (Table 2). The substances Emamectin benzoate (CASRN 137512-74-4), avermectin B1 (CASRN 71751-41-2), ally (CASRN 74223-64-6), butachlor (CASRN 23184-66-9), propisochlor (CASRN 86763-47-5), butralin (CASRN 33629-47-9), fluoroglycofen (77501-90-7) were excluded in the life cycle impact assessment stage due to lack of emission-effect data in the USEtox model [38-40]. This may lead to an underestimate of the human and eco-toxicity potentials of both villages.

The emission factor for nitrous oxide $\left(\mathrm{N}_{2} \mathrm{O}\right)$ and ammonia $\left(\mathrm{NH}_{3}\right)$ were global mean values of the respective factors taken from previous studies [41-43]. The nitrogen, phosphorus, and potassium loss were set at $26 \%, 0.2 \%$, and $6.5 \%$ of the total amount applied, respectively [44]. On-farm emissions of greenhouse gas $\mathrm{CO}_{2}, \mathrm{CH}_{4}$, and $\mathrm{N}_{2} \mathrm{O}$ were from farmland machineries, and calculated using factors reported by $[9,45,46]$. The presence of heavy metal contents in agricultural fertilizers and manures were calculated based on ratios reported in the relevant literature [47-51].

\subsection{Life Cycle Impact Assessment}

Various models exist for performing life cycle impact assessments, but no one single method is suitable for all assessment requirements [26]. Given the data attributes and the assessment scope and goals of this study in a Chinese context, a combination of models was selected based upon careful review of relevant agricultural LCA studies [9,20,26,29,39,40,52-54], (Table 3). The global warming potential (GWP) over 100 years was calculated using the $\mathrm{CO}_{2}$ equivalent factors for global representation and comparison [54]. The eutrophication potential, water and land use were calculated 
based on worldwide normalization data [20]. The acidification potential was calculated using the molc $\mathrm{H}^{+}$equivalent method for better comparability [52]. Toxicity potentials were calculated based on the method described in the USETox manual [39].

Table 3. Life cycle impact assessment (LCIA) methodologies used in this study.

\begin{tabular}{|c|c|c|c|}
\hline Impact Category & Unit & LCIA Method Used & Reference \\
\hline Global warming & $\mathrm{kg} \mathrm{CO} 2 \mathrm{eq}$ & IPCC & IPCC, 2013 \\
\hline Eutrophication & $\mathrm{kg} \mathrm{PO}_{4}{ }^{3-} \mathrm{eq}$ & CML 2002 & Guinee et al. (2002) \\
\hline Acidification & molc $\mathrm{H}^{+}$eq & Accumulated exceedance & Posch et al. (2008) \\
\hline Human toxicity & CTUh $^{a}$ & USEtox model & Rosenbaum et al. (2008) \\
\hline Ecotoxicity & CTUh $^{\mathrm{a}}$ & USEtox model & Rosenbaum et al. (2008) \\
\hline Water use & $\mathrm{L}$ & CML 2002 & Guinee et al. (2002) \\
\hline Land use & $\mathrm{m}^{2} \cdot$ year & CML 2002 & Guinee et al. (2002) \\
\hline
\end{tabular}

eq., equivalent; IPCC, Intergovernmental Panel on Climate Change; ${ }^{a}$ midpoint characterization factors were used for toxicity impacts.

Even though all current life cycle impact assessment models for toxicity account for the impact of pesticides once they are emitted into the natural environment [55], there is no consensus model on the emission factors of pesticides for both on and off-field environments [39,55-57]. The present study selected the USEtox model as it treats agricultural soil as a separate emission media, thus allowing for on-site emissions leading to the human and freshwater toxicity potential to be summarized using the amount of pesticides applied in the field [55]. Also, the USEtox model provides the largest substance database available with a higher precision on mid- and end-point toxicity outcomes than other models [39], making it a better choice, as in this case, when multiple chemicals are involved.

Twelve of the nineteen pesticides identified were included in the final calculation (Table 2); seven were excluded due to a lack of human and eco-toxicological data in the USEtox database. Characterization factors for the midpoint human toxicity potential in comparative toxic units (CTUh, cases $/ \mathrm{kg}_{\text {emitted }}$ ) and the midpoint freshwater ecotoxicity potential in comparative toxic units (CTUe, $\mathrm{PAF} \times \mathrm{m} 3 / \mathrm{kg}_{\text {emitted }}$, where PAF stands for potentially affected fraction of species) were modeled using the USEtox 2.01 version $[38,40]$.

\section{Results}

\subsection{Resource Use in Vegetable Cultivation}

Direct resource usage largely reflects the production efficiency of a cropping system. In this study, results showed that the farmland (ha), diesel (L), water (L), and electricity $(\mathrm{kWh})$ used to produce $10,000 \mathrm{NE}$ units for vegetable cultivation in village $\mathrm{CZ}$ were all lower than those used for conventional wheat/maize cultivation in village ZCP, with decreases of $69.8 \%, 62.2 \%, 71.7 \%$, and $63.4 \%$, respectively. The average nitrogen, phosphorus, and potassium input levels required to produce 10,000 NE units in village $\mathrm{CZ}$ were also all lower than those of village $\mathrm{ZCP}$, by $16.3 \%, 42.1 \%$, and $75.8 \%$, respectively. These results clearly indicated the increased sustainability of the multi-cropping system.

\subsection{Global Warming, Eutrophication, and Acidification Potentials}

The global warming potential, eutrophication potential, and acidification potential of producing equal amounts of NE units were all lower for the vegetable cultivation system in $\mathrm{CZ}$ than for the wheat/maize system in ZCP (Table 4). They were calculated using emission factors described in the life cycle inventory and models described in Table 3.

The total global warming potential, almost entirely dominated by the emission of nitrogen oxides and carbon dioxides in both systems, decreased by $21.6 \%$ in the vegetable cultivation system (Table 4 ). Within the total global warming potential categories, those caused by the emission of NOx decreased by $16.3 \%$, and those caused by the emission of $\mathrm{CO}_{2}$ decreased by $71.8 \%$ (Table 4 ). 
Table 4. Pollutants emitted producing 10,000 nutrient equivalent units in villages CZ and ZCP.

\begin{tabular}{rcc}
\hline \multicolumn{1}{l}{ Village } & $\mathrm{CZ}$ & ZCP \\
\hline Global warming potential & $1.95 \times 10^{3}$ & $2.49 \times 10^{3}$ \\
from $\mathrm{NO}_{\mathbf{X}}$ emission & $1.89 \times 10^{3}$ & $2.26 \times 10^{3}$ \\
$\mathrm{CO}_{2}$ emission & $6.55 \times 10^{1}$ & $2.33 \times 10^{2}$ \\
$\mathrm{CH}_{4}$ emission & $3.60 \times 10^{-3}$ & $1.28 \times 10^{-2}$ \\
Eutrophication potential & $6.42 \times 10^{1}$ & $7.71 \times 10^{1}$ \\
from N loss & $3.19 \times 10^{1}$ & $3.82 \times 10^{1}$ \\
$\mathrm{P}$ loss & $4.58 \times 10^{-1}$ & $7.90 \times 10^{-1}$ \\
$\mathrm{NH}_{3}$ emission & $3.10 \times 10^{1}$ & $3.71 \times 10^{1}$ \\
$\mathrm{NO}_{X}$ emission & $8.23 \times 10^{-1}$ & $9.85 \times 10^{-1}$ \\
Acidification potential & $2.73 \times 10^{2}$ & $3.26 \times 10^{2}$ \\
from $\mathrm{NH}_{3}$ emission & $2.68 \times 10^{2}$ & $3.20 \times 10^{2}$ \\
$\mathrm{NO}_{\mathbf{X}}$ emission & 4.69 & 5.61 \\
$\mathrm{SO}_{x}$ emission & $1.08 \times 10^{-1}$ & $3.82 \times 10^{-1}$ \\
\hline
\end{tabular}

Both systems suffered from high eutrophication potentials caused by total nitrogen loss (leaching) to the soil and the volatilization of $\mathrm{NH}_{3}$ to the air. The total eutrophication potential decreased by $16.7 \%$ in the vegetable cultivation system, with potentials from nitrogen loss, phosphorus loss, $\mathrm{NH}_{3}$ emission, and NOx emission decreasing by $16.4 \%, 42.0 \%, 16.4 \%$, and $16.4 \%$, respectively (Table 4 ).

The total acidification potentials in both systems were mainly from volatilized $\mathrm{NH}_{3}$ emissions to the air (Table 4). The vegetable cultivation system caused $16.26 \%$ less acidification potential compared to that caused by the traditional wheat/maize rotation system.

\subsection{Toxicity Potentials}

The toxicity impact data comprises the effects of 12 pesticides and 4 heavy metals on the midpoint human toxicity potential, measured in disease cases, both carcinogenic and non-carcinogenic, per kg of substance emitted, and on the midpoint eco-toxicity potential, measured in a potentially affected fraction of species per kg of substance emitted (Table 5) [25,47-49] Pesticides and heavy metal remnants represent two distinctive aspects of toxicity and were therefore compared and presented separately.

Table 5. Characterization factors (CF) and midpoint human (CTUh) and eco-toxicity (CTUe) potentials of the substances being used in villages $\mathrm{CZ}$ and ZCP calculated using USEtox.

\begin{tabular}{|c|c|c|c|c|c|c|c|}
\hline \multirow{2}{*}{ CAS RN } & \multirow{2}{*}{ Substance } & \multirow{2}{*}{ CTUh CF ${ }^{1}$} & \multirow{2}{*}{ CTUe CF ${ }^{2}$} & \multicolumn{2}{|c|}{$\mathrm{CZ}$} & \multicolumn{2}{|c|}{$\mathrm{ZCP}$} \\
\hline & & & & CTUh & CTUe & CTUh & CTUe \\
\hline $1113-02-6$ & Dimethoxon & $3.33 \times 10^{-2}$ & $1.72 \times 10^{2}$ & $1.99 \times 10^{-2}$ & $1.03 \times 10^{2}$ & $2.76 \times 10^{-2}$ & $1.43 \times 10^{2}$ \\
\hline $52315-07-8$ & Cypermethrin & $3.33 \times 10^{-2}$ & $6.19 \times 10^{4}$ & $6.94 \times 10^{-3}$ & $1.29 \times 10^{4}$ & $6.45 \times 10^{-4}$ & $1.20 \times 10^{3}$ \\
\hline $10265-92-6$ & Methamidphos & $s 1.08 \times 10^{-5}$ & $1.72 \times 10^{2}$ & $7.08 \times 10^{-8}$ & 1.13 & $7.98 \times 10^{-7}$ & $1.27 \times 10^{1}$ \\
\hline $138261-41-3$ & Imidacloprid & $3.33 \times 10^{-2}$ & $1.93 \times 10^{3}$ & $7.14 \times 10^{-5}$ & 4.14 & $6.24 \times 10^{-6}$ & $3.62 \times 10^{-1}$ \\
\hline $80-06-8$ & Dimite & $4.15 \times 10^{-6}$ & $7.68 \times 10^{2}$ & $2.27 \times 10^{-9}$ & $4.20 \times 10^{1}$ & $1.06 \times 10^{-7}$ & $2.00 \times 10^{1}$ \\
\hline $14816-18-3$ & Phoxim & $\mathrm{NA}^{3}$ & $1.43 \times 10^{2}$ & 0 & $1.05 \times 10^{1}$ & 0 & $5.17 \times 10^{-1}$ \\
\hline 57966-95-7 & Cymoxanil & $3.34 \times 10^{-7}$ & $1.83 \times 10^{2}$ & $3.72 \times 10^{-11}$ & $2.04 \times 10^{-2}$ & 0 & 0 \\
\hline $8018-01-7$ & Mancozeb & NA & $4.43 \times 10^{3}$ & 0 & 3.95 & 0 & 0 \\
\hline $1897-45-6$ & Chlorothalonil & $1.62 \times 10^{-5}$ & $3.59 \times 10^{4}$ & $7.39 \times 10^{-8}$ & $1.64 \times 10^{2}$ & 0 & 0 \\
\hline $1912-24-9$ & Arazine & $1.49 \times 10^{-5}$ & $8.55 \times 10^{3}$ & $2.29 \times 10^{-7}$ & $1.31 \times 10^{2}$ & $1.15 \times 10^{-6}$ & $6.62 \times 10^{2}$ \\
\hline $40487-42-1$ & Pendimethalin & $1.22 \times 10^{-4}$ & $6.58 \times 10^{3}$ & $1.34 \times 10^{-5}$ & $7.21 \times 10^{2}$ & $3.36 \times 10^{-6}$ & $1.81 \times 10^{2}$ \\
\hline $34256-82-1$ & Acetochlor & $2.17 \times 10^{-7}$ & $2.55 \times 10^{3}$ & $1.44 \times 10^{-9}$ & $1.70 \times 10^{1}$ & $7.83 \times 10^{-9}$ & $9.22 \times 10^{1}$ \\
\hline $22537-48-0$ & $\mathrm{Cd}(\mathrm{II})$ & 1.24 & $5.46 \times 10^{6}$ & $2.50 \times 10^{-3}$ & $1.10 \times 10^{4}$ & $5.41 \times 10^{-5}$ & $2.37 \times 10^{2}$ \\
\hline $14280-50-3$ & $\mathrm{~Pb}(\mathrm{II})$ & $2.86 \times 10^{-1}$ & $3.03 \times 10^{3}$ & $3.88 \times 10^{-3}$ & $4.10 \times 10^{1}$ & $4.98 \times 10^{-5}$ & $5.26 \times 10^{-1}$ \\
\hline $15158-11-9$ & $\mathrm{Cu}(\mathrm{II})$ & $4.60 \times 10^{-4}$ & $3.98 \times 10^{7}$ & $3.91 \times 10^{-4}$ & $3.40 \times 10^{7}$ & $8.20 \times 10^{-9}$ & $7.10 \times 10^{2}$ \\
\hline $23713-49-7$ & $\mathrm{Zn}(\mathrm{II})$ & $1.02 \times 10^{-1}$ & $3.49 \times 10^{5}$ & $1.28 \times 10^{-1}$ & $4.40 \times 10^{7}$ & $2.16 \times 10^{-5}$ & $7.38 \times 10^{1}$ \\
\hline
\end{tabular}

The total midpoint human toxicity potential derived from pesticide active ingredients for $\mathrm{CZ}$ was $4.9 \%$ lower than that of ZCP (Table 5). The highest pesticide contributor to CTUh in both villages was 
Dimethoxon (also known as Omethoate), a systemic organophosphorus insecticide used for insects and mites (Figure 2). Along with Cypermethrin and Imidacloprid, it had the highest midpoint human toxicity characterization factor (Table 5). However, the total midpoint eco-toxicity potential derived from pesticide active ingredients in $\mathrm{CZ}$ was more than five times that of $\mathrm{ZCP}$, which was mainly attributable to an increased use of Cypermethrin, a synthetic pyrethroid insecticide, in CZ (Table 5).

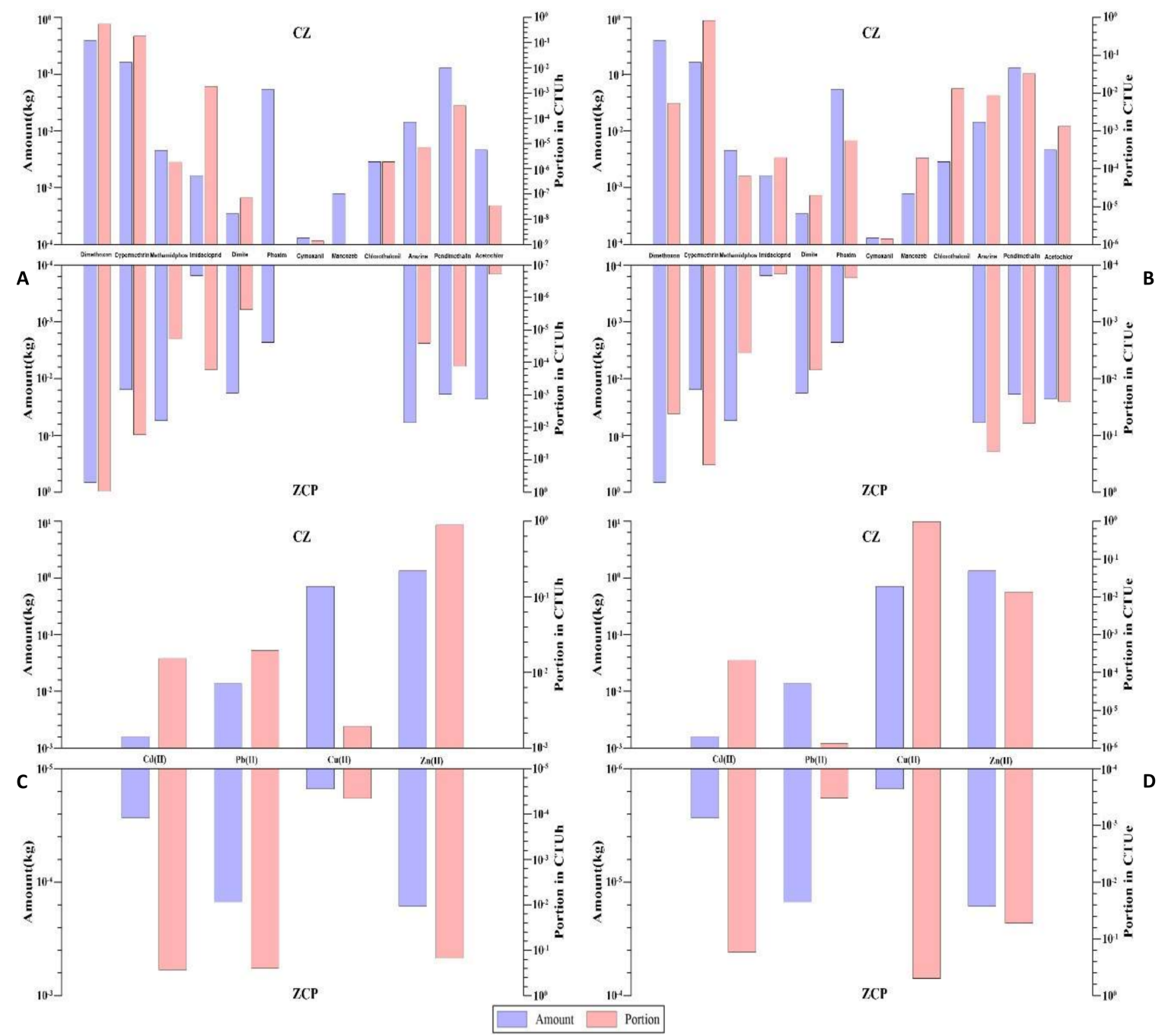

Figure 2. Amount of individual pesticides and heavy metals in the two cropping types and their respective portion within the total human and eco-toxicity potentials (A) midpoint human toxicity comparison of pesticides; (B) midpoint eco-toxicity comparison of pesticides; (C) midpoint human toxicity comparison of heavy metals; (D) midpoint eco-toxicity comparison of heavy metals). Pesticides and heavy metals are presented separately. Each value on the Y-axes is presented with its significand (from 0.1-9.9 within the matching exponent section) and its exponent for better data coverage.

Heavy metal contributed highly to both the midpoint human and eco-toxicity potentials in CZ. Both toxicity potentials in $\mathrm{CZ}$ were higher than those of $\mathrm{ZCP}$ by orders of magnitudes. The elements $\mathrm{Cu}$ and $\mathrm{Zn}$ were the top two contributors (Table 5; Figure 2). These resulted from an increasing use of manures in village $\mathrm{CZ}$ (Table 2).

\section{Discussion}

Fengqiu County is a typical agricultural region in the lower Yellow River basin. Its numerous cultivation patterns are the result of historical, natural, and anthropogenic activities. Current Chinese 
policies regarding rural development call for a unified monoculture of food crops connecting the once fragmented farming landscapes, attempting to boost resource efficiency, raise the total yield, and reduce chemical use in the process. The diverse vegetable farming system in the present study, however, represents an economically viable alternative to the vast monocultures capable of achieving such goals. Using life cycle assessment methodology, we obtained detailed cultivation data, and comprehensively assessed the environmental impacts of all compartments related to the on-site cultivation processes of the two farming systems. We also proposed the use of nutritional equivalents as a novel functional unit when assessing complex farming systems.

Even though vegetable multi-cropping requires a considerably higher input of resources (Table 2), results show that this system could increase resource efficiency, and reduce the overall emissions of pollutants that lead to global warming, eutrophication, and acidification to produce an equal amount of nutrient equivalents when compared with a conventional wheat/maize rotation system. The elevated resource efficiency is most likely due to the combination of multiple vegetable crops, each with unique nutrient dispositions and growth periods, intercropping and succeeding one another, creating a highly efficient and complementary use of available spatial and temporal resources [14,15,58-60]. Local interview results indicated that while the nutrient requirements of wheat/maize systems rose over the years to support a fluctuating yield, the resource inputs in the multi-cropping system remained stable. This likely points to a more sustainable soil condition in the multi-cropping system, which might have been the result of the increased biological remediation of multi-cropping [14,16].

The causes of larger scale environmental impacts need to be identified in agricultural practices. In this study, the main contributors for global warming potentials in both villages were $\mathrm{NO}_{\mathrm{X}}$ and $\mathrm{CO}_{2}$ emissions, caused by nitrogen fertilizer and diesel usage, respectively; the main contributors for eutrophication potentials in both villages were total nitrogen loss (leaching) and $\mathrm{NH}_{3}$ emission, both caused by extensive nitrogen fertilizer usage; the main contributors for acidification potentials were $\mathrm{NH}_{3}$ and $\mathrm{NO}_{X}$ emissions, caused by nitrogen fertilizer usage (Table 4). It was clear that all of these pollutants resulted from fertilizer input in the cultivation processes $[42,61,62]$. The vegetable multi-cropping presented in this case involved crop types from various genera and families, even orders (Table 1), which would increase soil cover and root presence in the topsoil both spatially and temporally, thus reducing the risk for run-off and nitrate leaching [63,64]. Even though existing data cannot provide a detailed emission model for various pollutants in a multi-cropping environment, it is reasonable to assume that the vegetable multi-cropping system in this case would cause even fewer environment impacts.

The human and ecological toxicity impacts caused by farming practices can come from various sources, including pollutant emissions, pesticides, and heavy metals from fertilizers and other chemicals [21]. Pesticides and heavy metals are particularly alarming factors as they usually pertain to longer-lasting and more toxic substances [20]. In this study, the USEtox toxicity model was selected to better establish the fate of pesticides and heavy metal elements, and their toxicity implications based on direct cause-effect chains [39].

Toxicity results indicate that when analyzed separately, vegetable multi-cropping practices could generate smaller human toxicity potentials, despite their high pesticide usage. The overall human and eco-toxicity effect rested largely on the selection of few pesticides. In the present study, cypermethrin's high midpoint eco-toxicity characterization factor (Table 5) made it the largest contributor to the total eco-toxicity potentials in both villages ( $91.7 \%$ and $51.8 \%$ in villages $\mathrm{CZ}$ and ZCP, respectively). Because of its acute and high toxicity to fish, bees and aquatic insects [65], alternative pyrethroid compounds have been developed that pose a lesser threat to the environment [66,67]. Since the pesticide market in rural China generally lags behind international advances, it is possible that by adopting newer and less toxic pesticides, the vegetable multi-cropping system can be made more sustainable in terms of human and eco-toxicity potentials.

The toxicity potentials posed by heavy metals from manure remnants were of major concern in the vegetable multi-cropping system. Chicken manure was the main source of nutrients in vegetable 
multi-cropping (Table 2), and because of its high heavy metal content compared to other nutrient sources $[51,68]$, it was the main contributor of heavy metal contaminants in the system. Local manure compost was a crude process in that no specific container or additives were used. But previous research indicated that by adding bioaccumulation agents such as earthworms $[69,70]$ in the compost process, the contamination of heavy metal elements could be considerably reduced. Such practices need to be adopted in the present vegetable multi-cropping system to minimize the total toxicological potentials.

The scope of the study was set at gate-to-gate, limited to farmland cultivation practices and their impact at the local scale with a focus on the differences between the cultivation methods of the two cropping systems. However, agricultural environmental impacts are not limited to the field. A broader and more extensive evaluation and comparison of the environmental impacts of the cropping systems would need to consider off-farm data, such as the production and transportation of materials. Furthermore, due to the lack of a comprehensive Chinese agricultural life cycle assessment framework, the LCIA models used in this study were international models rather than tailored to the regional context. This would inevitably lead to a certain degree of over-generalisation in the assessment results. Chinese agricultural LCA studies could benefit from more specific and regionalized LCA databases which would help researchers build cases-specific models in the future.

A sensitivity analysis helps to understand the impact of the methodological choices on the LCA results. The case study in this paper sheds light on how the farm-level cultivation practices of multi-cropping can affect the environment. Beside the study's scope, the choice of impact assessment methods is another important factor that would affect the outcome. The major differences, and the main source of uncertainty, arise from the vastly different chemical (insecticide, herbicide, and fungicide) and raw manure application patterns between the two villages (Table 2). Normally, in order to obtain reliable and representative LCA results, the extent of the associated uncertainty must be estimated by using different toxicity models. However, toxicity models other than the USEtox could not accommodate such a variety of chemical substances. Thus, using other models would mean a selective representation of the inputs, and would only add to the level of uncertainty, rather than substantiating our results.

\section{Conclusions}

The urgent need to decrease external inputs in agricultural production calls for revolutionary approaches, especially in the context of agricultural biodiversity. Results of this albeit limited study demonstrated clear differences in the environmental impacts of cultivation practices between vegetable multi-cropping and a traditional wheat/maize rotation system. Intercropping and planting different vegetables in succession are able to maximize resource use efficiency and generate equal returns at considerably less environmental costs than a traditional system. The vegetable multi-cropping system also resulted in reduced global warming, eutrophication, and acidification potentials. With the ever-growing domestic need to grow more food on less farmland with limited resources, this highly diverse cultivation system can provide valuable insights for future sustainable development in agriculture. As fertilizer is a major contributor to the environmental impacts of agricultural production, this research also pointed out that farming systems could reduce environmental impacts by adapting advanced technologies, such as formula fertilization via soil testing and the bioaccumulation of heavy metals. From a policy making perspective, encouraging agricultural biodiversity practices could provide effective pathways for alleviating the existing stress from China's man-land relationship.

Acknowledgments: The authors wish to thank the Bureau of Statistics and the Bureau of Agriculture of Fengqiu County for their assistance in village selections and interview preparations. We also wish to thank the leaders of the two study villages for their continuous effort in supporting our household interviews. This work was supported by The National Key Research and Development Program of China (2016YFD0800906).

Author Contributions: $\mathrm{Li} \mathrm{Li}$, Paul Giller, and John O'Halloran conceived and designed the underlying experiments; Li Li performed the experiments and analyzed the data; Wenliang Wu, Long Liang, and Peng Peng contributed analysis tools; $\mathrm{Li} \mathrm{Li}$ and Guishen Zhao wrote the paper. 
Conflicts of Interest: The authors declare no conflict of interest. The founding sponsors had no role in the design of the study; in the collection, analyses, or interpretation of data; in the writing of the manuscript, and in the decision to publish the results.

\section{Appendix A}

Table A1. List of fertilizers and pesticides used in the two study villages.

\begin{tabular}{|c|c|c|}
\hline Agricultural input & $\mathrm{CZ}$ & $\mathrm{ZCP}$ \\
\hline \multicolumn{3}{|l|}{ Fertilizer $\left(\mathrm{N}-\mathrm{P}_{2} \mathrm{O}_{5}-\mathrm{K}_{2} \mathrm{O}\right.$ equivalent when applicable) } \\
\hline XLX Comp. $(25-7-8)$ & + & + \\
\hline Carbamide & + & + \\
\hline XY Comp. (18-7-20) & + & + \\
\hline Diammonium phosphate & + & + \\
\hline Ammonium bicarbonate & + & + \\
\hline FT Comp. (18-17-10) & & + \\
\hline Stanley Comp. (25-10-16) & + & + \\
\hline Potassium Phosphate Monobasic & + & \\
\hline Phosphate nitrate & + & \\
\hline Apollo Comp. (15-15-15) & + & \\
\hline WFT Comp. (16-16-16) & + & \\
\hline Chicken manure & + & + \\
\hline Swine manure & + & \\
\hline \multicolumn{3}{|l|}{ Insecticide } \\
\hline YHLG (40\% dimethoxon EC) & + & + \\
\hline $\mathrm{JZ}$ (4.5\% cypermethrin EC) & + & + \\
\hline JAL (25\% methamidphos EC) & + & + \\
\hline JWY $(3 \%$ emamectin EC) & & + \\
\hline JGZ ( $0.5 \%$ emamectin, $4.5 \%$ cypermethrin EC) & & + \\
\hline BCL (5\% imidacloprid EC) & & + \\
\hline XLL ( $45 \%$ valaxon EC) & + & + \\
\hline SMC (40\% dimite EC) & & + \\
\hline \multicolumn{3}{|l|}{ Fungicide } \\
\hline DuPont KL (72\% curzate WP) & + & \\
\hline SNMX (32\% dsmx, $4 \%$ snq WP) & + & \\
\hline \multicolumn{3}{|l|}{ Herbicide } \\
\hline JHL (20\% ally WDG) & & + \\
\hline YNS ( $4 \%$ butachlor, $20 \%$ propisochlor, $18 \%$ atrazine EC) & + & + \\
\hline DLA $(48 \%$ butralin EC) & + & + \\
\hline STB $(33 \%$ pendimethalin EC) & + & + \\
\hline YCJ $(15 \%$ atrazine EC) & + & + \\
\hline YBCY (16\% propisochlor, $26 \%$ atrazine EC) & & + \\
\hline GK $(10 \%$ fluoroglycofen EC) & + & + \\
\hline YCA (50\% acetochlor EC) & + & + \\
\hline DCA (50\% napropamide WP) & + & \\
\hline
\end{tabular}

Substances represented by acronyms of their Chinese common names; Comp. stands for compound fertilizer; EC, emulsifiable concentrate; WP, wettable powder; WDG, water dispersible granules. 
Table A2. Calculation of the nutritional equivalents of the produces (daily values for the nutrients are calories $11,290 \mathrm{KJ}^{-1 a y}{ }^{-1}$, vitamin A $800 \mu \mathrm{g}$ day ${ }^{-1}$, carotene

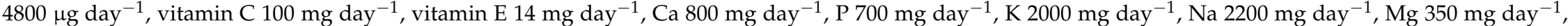
Fe $15 \mathrm{mg} \mathrm{day}^{-1}, \mathrm{Zn} 15 \mathrm{mg} \mathrm{day}^{-1}$, Se $50 \mu \mathrm{g} \mathrm{day}^{-1}, \mathrm{Cu}_{2} \mathrm{mg}_{\text {day }}{ }^{-1}, \mathrm{Mn} 3.5 \mathrm{mg}$ day $^{-1}$ ).

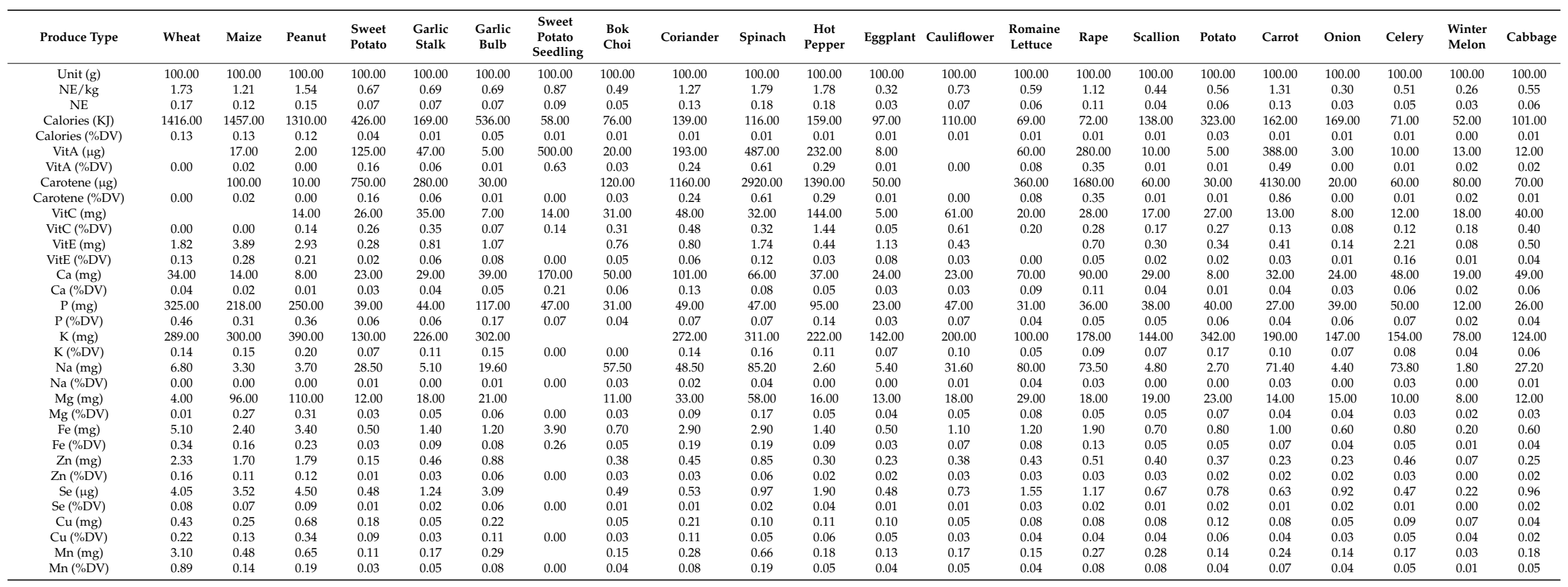




\section{References}

1. Power, A.G. Ecosystem services and agriculture: Tradeoffs and synergies. Philos. Trans. R. Soc. B 2010, 365, 2959-2971. [CrossRef] [PubMed]

2. Wood, S.A.; Karp, D.S.; DeClerck, F.; Kremen, C.; Naeem, S.; Palm, C.A. Functional traits in agriculture: Agrobiodiversity and ecosystem services. Trends Ecol. Evol. 2015, 30, 531-539. [CrossRef] [PubMed]

3. Altieri, M.A. The ecological role of biodiversity in agroecosystems. Agric. Ecosyst. Environ. 1999, 74, $19-31$. [CrossRef]

4. Gardner, T.A.; Barlow, J.; Chazdon, R.; Ewers, R.M.; Harvey, C.A.; Peres, C.A.; Sodhi, N.S. Prospects for tropical forest biodiversity in a human-modified world. Ecol. Lett. 2009, 12, 561-582. [CrossRef] [PubMed]

5. Friedlingstein, P.; Houghton, R.; Marland, G.; Hackler, J.; Boden, T.A.; Conway, T.; Canadell, J.; Raupach, M.; Ciais, P.; Le Quere, C. Update on $\mathrm{CO}_{2}$ emissions. Nat. Geosci. 2010, 3, 811-812. [CrossRef]

6. Food and Agriculture Organization, U.N. Faostat. 2016. Available online: http://faostat3.fao.org/faostatgateway/go/to/home/E (accessed on 20 June 2016).

7. Zhang, C.; Hu, R.; Shi, G.; Jin, Y.; Robson, M.G.; Huang, X. Overuse or underuse? An observation of pesticide use in china. Sci. Total Environ. 2015, 538, 1-6. [CrossRef] [PubMed]

8. Burney, J.A.; Davis, S.J.; Lobell, D.B. Greenhouse gas mitigation by agricultural intensification. Proc. Natl. Acad. Sci. USA 2010, 107, 12052-12057. [CrossRef] [PubMed]

9. He, X.; Qiao, Y.; Liang, L.; Knudsen, M.T.; Martin, F. Environmental life cycle assessment of long-term organic rice production in subtropical china. J. Clean. Prod. 2018, 176, 880-888. [CrossRef]

10. Feng, J.; Chen, C.; Zhang, Y.; Song, Z.; Deng, A.; Zheng, C.; Zhang, W. Impacts of cropping practices on yield-scaled greenhouse gas emissions from rice fields in China: A meta-analysis. Agric. Ecosyst. Environ. 2013, 164, 220-228. [CrossRef]

11. Ju, X.T.; Xing, G.X.; Chen, X.P.; Zhang, S.L.; Zhang, L.J.; Liu, X.J.; Cui, Z.L.; Yin, B.; Christie, P.; Zhu, Z.L.; et al. Reducing environmental risk by improving $\mathrm{n}$ management in intensive chinese agricultural systems. Proc. Natl. Acad. Sci. USA 2009, 106, 3041-3046. [CrossRef] [PubMed]

12. Qu, Z.; Wang, J.; Almøy, T.; Bakken, L.R. Excessive use of nitrogen in chinese agriculture results in high $\mathrm{n} 2 \mathrm{o} /(\mathrm{n} 2 \mathrm{o}+\mathrm{n} 2)$ product ratio of denitrification, primarily due to acidification of the soils. Glob. Chang. Biol. 2014, 20, 1685-1698. [CrossRef] [PubMed]

13. Guo, J.H.; Liu, X.J.; Zhang, Y.; Shen, J.L.; Han, W.X.; Zhang, W.F.; Christie, P.; Goulding, K.W.T.; Vitousek, P.M.; Zhang, F.S. Significant acidification in major chinese croplands. Science 2010, 327, 1008-1010. [CrossRef] [PubMed]

14. Malézieux, E.; Crozat, Y.; Dupraz, C.; Laurans, M.; Makowski, D.; Ozier-Lafontaine, H.; Rapidel, B.; de Tourdonnet, S.; Valantin-Morison, M. Mixing plant species in cropping systems: Concepts, tools and models: A review. In Sustainable Agriculture; Lichtfouse, E., Navarrete, M., Debaeke, P., Véronique, S., Alberola, C., Eds.; Springer: Dordrecht, The Netherlands, 2009.

15. Tosti, G.; Guiducci, M. Durum wheat-faba bean temporary intercropping: Effects on nitrogen supply and wheat quality. Eur. J. Agron. 2010, 33, 157-165. [CrossRef]

16. Altieri, M.A. Agroecology: The Science of Sustainable Agriculture; Westview Press: Boulder, CO, USA, 1995; p. 448.

17. Ehrmann, J.; Ritz, K. Plant: Soil interactions in temperate multi-cropping production systems. Plant Soil 2013, 376, 1-29. [CrossRef]

18. Notarnicola, B.; Salomone, R.; Petti, L.; Renzulli, P.A.; Roma, R.; Cerutti, A.K. Life Cycle Assessment in the Agri-Food Sector: Case Studies, Methodological Issues and Best Practices; Springer International Publishing: Basel, Switzerland, 2015.

19. Curran, M.A. Life cycle assessment: A review of the methodology and its application to sustainability. Curr. Opin. Chem. Eng. 2013, 2, 273-277. [CrossRef]

20. Guinée, J.B. Handbook on Life Cycle Assessment: Operational Guide to the Iso Standards; Springer: Dordrecht, The Netherlands, 2002.

21. Brentrup, F.; Küsters, J.; Kuhlmann, H.; Lammel, J. Environmental impact assessment of agricultural production systems using the life cycle assessment methodology. Eur. J. Agron. 2004, 20, 247-264. [CrossRef] 
22. Sonesson, U.; Davis, J.; Flysjö, A.; Gustavsson, J.; Witthöft, C. Protein quality as functional unit-A methodological framework for inclusion in life cycle assessment of food. J. Clean. Prod. 2017, 140, 470-478. [CrossRef]

23. Kulak, M.; Nemecek, T.; Frossard, E.; Gaillard, G. How eco-efficient are low-input cropping systems in western europe, and what can be done to improve their eco-efficiency? Sustainability 2013, 5, 3722-3743. [CrossRef]

24. Notarnicola, B.; Sala, S.; Anton, A.; McLaren, S.J.; Saouter, E.; Sonesson, U. The role of life cycle assessment in supporting sustainable agri-food systems: A review of the challenges. J. Clean. Prod. 2017, 140, 399-409. [CrossRef]

25. Zhao, F.J.; Ma, Y.; Zhu, Y.G.; Tang, Z.; McGrath, S.P. Soil contamination in China: Current status and mitigation strategies. Environ. Sci. Technol. 2015, 49, 750-759. [CrossRef] [PubMed]

26. Hauschild, M.Z.; Goedkoop, M.; Guinée, J.; Heijungs, R.; Huijbregts, M.; Jolliet, O.; Margni, M.; De Schryver, A.; Humbert, S.; Laurent, A.; et al. Identifying best existing practice for characterization modeling in life cycle impact assessment. Int. J. Life Cycle Assess. 2012, 18, 683-697. [CrossRef]

27. Martínez-Blanco, J.; Lazcano, C.; Christensen, T.H.; Muñoz, P.; Rieradevall, J.; Møller, J.; Antón, A.; Boldrin, A. Compost benefits for agriculture evaluated by life cycle assessment. A review. Agron. Sustain. Dev. 2013, 33, 721-732. [CrossRef]

28. Munkholm, L.J.; Heck, R.J.; Deen, B. Long-term rotation and tillage effects on soil structure and crop yield. Soil Tillage Res. 2013, 127, 85-91. [CrossRef]

29. Wang, C.; Li, X.; Gong, T.; Zhang, H. Life cycle assessment of wheat-maize rotation system emphasizing high crop yield and high resource use efficiency in quzhou county. J. Clean. Prod. 2014, 68, 56-63. [CrossRef]

30. Soil Survey Staff. Illustrated Guide to Soil Taxonomy; U.S. Department of Agriculture; Natural Resources Conservation Service; National Soil Survey Center: Lincoln, Nebraska, 2015.

31. Charles, R.; Jolliet, O.; Gaillard, G.; Pellet, D. Environmental analysis of intensity level in wheat crop production using life cycle assessment. Agric. Ecosyst. Environ. 2006, 113, 216-225. [CrossRef]

32. Renouf, M.; Wegener, M.; Nielsen, L. An environmental life cycle assessment comparing australian sugarcane with us corn and uk sugar beet as producers of sugars for fermentation. Biomass Bioenerg. 2008, 32, 1144-1155. [CrossRef]

33. Roy, P.; Nei, D.; Orikasa, T.; Xu, Q.; Okadome, H.; Nakamura, N.; Shiina, T. A review of life cycle assessment (lca) on some food products. J. Food Eng. 2009, 90, 1-10. [CrossRef]

34. Martínez-Blanco, J.; Antón, A.; Rieradevall, J.; Castellari, M.; Muñoz, P. Comparing nutritional value and yield as functional units in the environmental assessment of horticultural production with organic or mineral fertilization. Int. J Life Cycle Assess. 2010, 16, 12-26. [CrossRef]

35. Tyszler, M.; Kramer, G.; Blonk, H. Comparing apples with oranges: On the functional equivalence of food products for comparative lcas. Int. J. Life Cycle Assess. 2014, 19, 1482-1487. [CrossRef]

36. National Institute for Nutrition and Health, C.C.D.C.P. China Food Composition, 2nd ed.; Peking University Medical Press: Beijing, China, 2009.

37. Yang, X.; Gao, W.; Zhang, M.; Chen, Y.; Sui, P. Reducing agricultural carbon footprint through diversified crop rotation systems in the north china plain. J. Clean. Prod. 2014, 76, 131-139. [CrossRef]

38. Henderson, A.D.; Hauschild, M.Z.; van de Meent, D.; Huijbregts, M.A.J.; Larsen, H.F.; Margni, M.; McKone, T.E.; Payet, J.; Rosenbaum, R.K.; Jolliet, O. Usetox fate and ecotoxicity factors for comparative assessment of toxic emissions in life cycle analysis: Sensitivity to key chemical properties. Int. J. Life Cycle Assess. 2011, 16, 701-709. [CrossRef]

39. Rosenbaum, R.K.; Bachmann, T.M.; Gold, L.S.; Huijbregts, M.A.J.; Jolliet, O.; Juraske, R.; Koehler, A.; Larsen, H.F.; MacLeod, M.; Margni, M.; et al. Usetox-The unep-setac toxicity model: Recommended characterisation factors for human toxicity and freshwater ecotoxicity in life cycle impact assessment. Int. J. Life Cycle Assess. 2008, 13, 532-546. [CrossRef]

40. Rosenbaum, R.K.; Huijbregts, M.A.J.; Henderson, A.D.; Margni, M.; McKone, T.E.; van de Meent, D.; Hauschild, M.Z.; Shaked, S.; Li, D.S.; Gold, L.S.; et al. Usetox human exposure and toxicity factors for comparative assessment of toxic emissions in life cycle analysis: Sensitivity to key chemical properties. Int. J. Life Cycle Assess. 2011, 16, 710-727. [CrossRef]

41. Bouwman, A.F.; Boumans, L.J.M.; Batjes, N.H. Modeling global annual $\mathrm{N}_{2} \mathrm{O}$ and no emissions from fertilized fields. Glob. Biogeochem. Cycles 2002, 16. [CrossRef] 
42. Mosier, A.; Kroeze, C.; Nevison, C.; Oenema, O.; Seitzinger, S.; Van Cleemput, O. Closing the global $\mathrm{N}_{2} \mathrm{O}$ budget: Nitrous oxide emissions through the agricultural nitrogen cycle-oecd/ipcc/iea phase II development of ipcc guidelines for national greenhouse gas inventory methodology. Nutr. Cycl. Agroecosyst. 1998, 52, 225-248. [CrossRef]

43. Stehfest, E.; Bouwman, L. $\mathrm{N}_{2} \mathrm{O}$ and no emission from agricultural fields and soils under natural vegetation: Summarizing available measurement data and modeling of global annual emissions. Nutr. Cycl. Agroecosyst. 2006, 74, 207-228. [CrossRef]

44. Lu, R.K.; Liu, H.X.; Wen, D.Z.; Qin, S.W.; Zheng, J.Y.; Wang, Z.Q. Study of the nutrient cycle and balance of agricultural ecosystems in chinese representative areas: I. Factors for farmland nutrients. Chin. J. Soil Sci. 1996, 4, 145-150. (In Chinese)

45. Hu, Z.Y.; Tan, P.Q.; Lou, D.M.; Dong, Y.Q. Life cycle emission assessment of diesel and its alternative fuels. Chi. Int. Combust. Engine Eng. 2007, 28, 80-85. (In Chinese)

46. Li, W.; Bai, H.; Yin, J.; Xu, H. Life cycle assessment of end-of-life vehicle recycling processes in china-Take corolla taxis for example. J. Clean. Prod. 2016, 117, 176-187. [CrossRef]

47. Yan, X.; Wang, X.; Li, X.Y.; Yu, Z.G. Contents, source and safety status of major heavy metals in water-soluble fertilizers in china. J. Plant. Nutr. Fertil. 2016, 22, 8-18. (In Chinese)

48. Wang, M.; Li, S.T. Heavy metals in fertilizers and effect of the fertilization on heavy metal accumulation in soils and crops. J. Plant. Nutr. Fertil. 2014, 20, 466-480. (In Chinese)

49. Alloway, B. Sources of heavy metals and metalloids in soils. In Heavy Metals in Soils; Alloway, B.J., Ed.; Springer: Dordrecht, The Netherlands, 2013.

50. Wei, B.; Yang, L. A review of heavy metal contaminations in urban soils, urban road dusts and agricultural soils from China. Microchem. J. 2010, 94, 99-107. [CrossRef]

51. Yao, L.X.; Li, G.L.; He, Z.H.; Fu, C.Y. Yield and heavy metal content of brassica parachinensis influenced by successive application of chicken manure. Environ. Sci. 2007, 28, 1113-1120. (In Chinese)

52. Liang, L.; Chen, Y.; Gao, W.; Sui, P.; Chen, D.; Zhang, W. Life cycle environmental impact assessment in winter wheat-summer maize system in north China plain. J. Agro-Environ. Sci. 2009, 28, 1773-1776.

53. Posch, M.; Seppäølä, J.; Hettelingh, J.-P.; Johansson, M.; Margni, M.; Jolliet, O. The role of atmospheric dispersion models and ecosystem sensitivity in the determination of characterisation factors for acidifying and eutrophying emissions in lcia. Int. J. Life Cycle Assess. 2008, 13, 477-486. [CrossRef]

54. Intergovernmental Panel on Climate Change. Climate Change 2013-The Physical Science Basis: Working Group I Contribution to the Fifth Assessment Report of the Intergovernmental Panel on Climate Change; Cambridge University Press: Cambridge, UK, 2014.

55. Rosenbaum, R.K.; Anton, A.; Bengoa, X.; Bjørn, A.; Brain, R.; Bulle, C.; Cosme, N.; Dijkman, T.J.; Fantke, P.; Felix, M.; et al. The glasgow consensus on the delineation between pesticide emission inventory and impact assessment for lca. Int. J. Life Cycle Assess. 2015, 20, 765-776. [CrossRef]

56. Pant, R.; Van Hoof, G.; Schowanek, D.; Feijtel, T.C.J.; De Koning, A.; Hauschild, M.; Olsen, S.I.; Pennington, D.W.; Rosenbaum, R.K. Comparison between three different lcia methods for aquatic ecotoxicity and a product environmental risk assessment: Insights from a detergent case study within omniitox. Int. J. Life Cycle Assess. 2004, 9, 295-306. [CrossRef]

57. Xue, X.; Hawkins, T.R.; Ingwersen, W.W.; Smith, R.L. Demonstrating an approach for including pesticide use in life-cycle assessment: Estimating human and ecosystem toxicity of pesticide use in midwest corn farming. Int. J. Life Cycle Assess. 2015, 20, 1117-1126. [CrossRef]

58. Nopper, J.; Lauströer, B.; Rödel, M.-O.; Ganzhorn, J.U. A structurally enriched agricultural landscape maintains high reptile diversity in sub-arid south-western madagascar. J. Appl. Ecol. 2017, 54, 480-488. [CrossRef]

59. Lichtenberg, E.M.; Kennedy, C.M.; Kremen, C.; Batáry, P.; Berendse, F.; Bommarco, R.; Bosque-Pérez, N.A.; Carvalheiro, L.G.; Snyder, W.E.; Williams, N.M.; et al. A global synthesis of the effects of diversified farming systems on arthropod diversity within fields and across agricultural landscapes. Glob. Chang. Biol. 2017, 23, 4946-4957. [CrossRef] [PubMed]

60. Turnbull, L.A.; Isbell, F.; Purves, D.W.; Loreau, M.; Hector, A. Understanding the value of plant diversity for ecosystem functioning through niche theory. Proc. Biol. Sci. 2016, 283. [CrossRef] [PubMed]

61. Nemecek, T.; von Richthofen, J.-S.; Dubois, G.; Casta, P.; Charles, R.; Pahl, H. Environmental impacts of introducing grain legumes into european crop rotations. Eur. J. Agron. 2008, 28, 380-393. [CrossRef] 
62. Scherer, L.; Pfister, S. Modelling spatially explicit impacts from phosphorus emissions in agriculture. Int. J. Life Cycle Assess. 2015, 20, 785-795. [CrossRef]

63. Wang, Y.; Zhang, B.; Lin, L.; Zepp, H. Agroforestry system reduces subsurface lateral flow and nitrate loss in jiangxi province, China. Agric. Ecosyst. Environ. 2011, 140, 441-453. [CrossRef]

64. George, S.J.; Harper, R.J.; Hobbs, R.J.; Tibbett, M. A sustainable agricultural landscape for australia: A review of interlacing carbon sequestration, biodiversity and salinity management in agroforestry systems. Agric. Ecosyst. Environ. 2012, 163, 28-36. [CrossRef]

65. United States Environmental Protection Agency. Reregistration Eligibility Decision for Cypermethrin; United States Environmental Protection Agency: Washington, DC, USA, 2008.

66. Elliott, M. The pyrethroids: Early discovery, recent advances and the future. Pestic. Sci. 1989, 27, 337-351. [CrossRef]

67. Hughes, J.; Reay, G.; Watson, J. Insecticide Use on Scottish Oilseed Rape Crops: Historical Use Patterns and Pest Control Options in the Absence of Neonicotinoid Seed Treatments; The Association for Crop Protection in Northern Britain: Dundee, UK, 2014.

68. Xiong, X.; Yanxia, L.; Wei, L.; Chunye, L.; Wei, H.; Ming, Y. Copper content in animal manures and potential risk of soil copper pollution with animal manure use in agriculture. Resour. Conserv. Recycl. 2010, 54, 985-990. [CrossRef]

69. Suthar, S.; Singh, S.; Dhawan, S. Earthworms as bioindicator of metals (zn, fe, mn, cu, pb and cd) in soils: Is metal bioaccumulation affected by their ecological category? Ecol. Eng. 2008, 32, 99-107. [CrossRef]

70. Nannoni, F.; Protano, G.; Riccobono, F. Uptake and bioaccumulation of heavy elements by two earthworm species from a smelter contaminated area in northern kosovo. Soil Biol. Biochem. 2011, 43, 2359-2367. [CrossRef]

(C) 2018 by the authors. Licensee MDPI, Basel, Switzerland. This article is an open access article distributed under the terms and conditions of the Creative Commons Attribution (CC BY) license (http:/ / creativecommons.org/licenses/by/4.0/). 